\title{
Xiang-ji-hof (hof vaxandi ilms) sótt heim ${ }^{1}$
}

$\mathrm{C}_{\text {tinda. }}^{\mathrm{g} \text { veit ekki hvar hofið er en klifið hef ég ófáa skýjum krýnda }}$ Ævaforn tré, hér er enginn á fero, og í djúpinu óma bjöllur.

Lækur gjálfrar við eggjagrjót undir húmgráum skuggum furutrjáa.

Í rökkrinu við hylinn, í hljóðri setu, vinn ég bug á eiturnöðrum.

\author{
《過香積寺》 \\ 不知香積寺, 數里入雲峰。古木無人徑, 深山何處鐘。 \\ 泉聲咽危石, 日色冷青松。薄暮空潭曲, 安禪制毒龍。
}

Jón Egill Eypórsson pýddi úr fornkinversku

1 Ljóðin eru pýdd eftir texta í: Chen Shuyuan, ritstj., Zhongguo Gudian Shici Shangdu Congshu: Wang Wei, Wuzhou- forlagið, Peking, 2005, Xiang-ji-hof bls. 117, Dádýrsgerði bls. 79 (中国 古典诗词精品赏读从书: 王维 / 陈殊原编著 北京: 五洲传播出版社, 2005).

Nafn hofsins Xiang-ji 香積 (uppsafnaður og vaxandi ilmur) kemur úr Vimalakirti-sútrunni 維 摩經. Sútra pessi var Wang Wei svo kær að hann tók sér skáldanafnið Mojie Jushi 摩诘居士 sem gerði honum kleift að mynda úr pví og eiginnafni sínu nafn sútrunnar (á kínversku Weimojiejing 維摩詰經). Xiang-ji香積 er nafn á Búddha sem dvelur á ódáinsakri meðal herskara angandi Bodhisattva. Á Tang 唐 tímanum stóð hof með pessu nafni í fjalllendi nálægt höfuðborginni Chang An 長安. Pað hefur verið endurreist nokkrum sinnum.

Í seinustu línunni vísar hljóð seta til zen-hugleiðslu og eiturnöðrur vísa til ókyrrðar auðginnts hugans. 